\title{
CADMIUM AND ZINC UPTAKE BY DRIED ACTIVATED SLUDGE: EQUILIBRIUM AND EXPERIMENTAL DESIGN STUDY
}

\author{
LUCIA REMENÁROVÁ ${ }^{1}$, MARTIN PIPÍŠKA ${ }^{1,2}$, MIROSLAV \\ HORNIIKK $^{1,2}$, JANA MAREŠOVÁ ${ }^{1}$, JOZEF AUGUSTÍN ${ }^{1,2}$ \\ ${ }^{I}$ Department of Ecochemistry and Radioecology, University of SS. Cyril \\ and Methodius, J. Herdu 2, Trnava, SK-917 01, Slovak Republic (pipiska@ucm.sk) \\ ${ }^{2}$ Consortium for Environmental Biotechnology and Environmental Chemistry, \\ Hlavná 418, Špačince, SK-919 51, Slovak Republic
}

\begin{abstract}
Removal of $\mathrm{Cd}^{2+}$ and $\mathrm{Zn}^{2+}$ ions from single and binary solutions by dried activated sludge was studied in batch experiments. It was shown that the metal removal is a rapid process significantly influenced by solution $\mathrm{pH}$. Maximum uptake of both $\mathrm{Cd}$ and $\mathrm{Zn}$ was reached at $\mathrm{pH} 6.0$ and negligible uptake was observed at $\mathrm{pH}$ 2.0. The Langmuir isotherm was found to well represent the measured equilibrium sorption data in single metal systems and the maximum sorption capacities $Q_{\max }$ of the activated sludge (d.w.), calculated from Langmuir model were $540 \pm 16 \mu \mathrm{mol} / \mathrm{g}$ for $\mathrm{Zn}^{2+}$ and $510 \pm 17 \mu \mathrm{mol} / \mathrm{g}$ for $\mathrm{Cd}^{2+}$ ions. The Response surface methodology (RSM) was used for investigation of interaction and competitive effects in binary metal system. It was found that dried activated sludge in binary system Cd-Zn has slightly higher affinity for $\mathrm{Cd}^{2+}$ comparing with $\mathrm{Zn}^{2+}$ ions. Competitive effect of $\mathrm{Cd}$ on $\mathrm{Zn}$ uptake increased with increasing solution $\mathrm{pH}$ and $\mathrm{Cd}$ initial concentration. Maximum sorption capacities of the activated sludge were 321

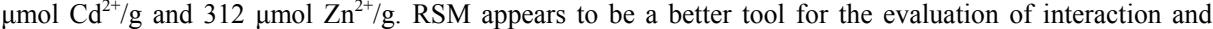
competitive effects in binary systems than both the simple extrapolation from single-component systems and experimentally difficult study of multi-component systems.
\end{abstract}

Key words: cadmium, zinc, biosorption, activated sludge, isotherms, RSM

\section{Introduction}

Industrial effluents contain both organic and inorganic pollutants. These pollutants upset natural balance in water ecosystems, interfere with organisms, accumulate in biota and enter into the food chain with human on the top. Contaminants removal by conventional treatment methods, such as chemical precipitation, membrane separation, evaporation and ion-exchange is often limited due to their low efficiency and economic viability (NAYAK and LAHIRI, 2006). Therefore, there is a need for an effective and economical treatment alternative. Biological processes such as biosorption and bioaccumulation represent possible interactions of toxic pollutants with biological systems in contaminated environment. Current research activity in the field attempts to evaluate whether biosorption may eventually provide such an effective and economical treatment process alternative (NAJA et al., 2010).

Many researchers studied biosorption from single systems (GHODBANE et al., 2008; KANG et al., 2007), although the degree of removal of metal ions from wastewaters by biosorption depends mainly on the competitive interactions of co-ions when present in solution (MA and TOBIN, 2003). Results from single component systems can provide useful data about the uptake capacity of used biosorbent, but they 
do not exactly reflect the real situation in wastewaters (GÖNEN and AKSU, 2009). Therefore it is necessary to study sorption process as complex process, which consists of many mechanisms and can be affected by many parameters. Effect of various parameters $(\mathrm{pH}$, temperature, sorbent particle size, initial concentration of sorbates) can be studied by the classical approach, when one variable is changed at a time. However this procedure represents a time consuming and less effective method. Multivariate optimization is faster and overcome circumstances not explained by the traditional methods such as interactions between the variables that influence the response e.g. sorption capacity (ZOLGHARNEIN et al., 2010). Response surface methodology (RSM) is a collection of mathematical and statistical techniques useful for designing experiments, building models and analyzing the effects of the several independent variables (MUNE et al., 2008). Main advantage of statistical design of experiments is the reduced number of experiments to be performed as well as it considers interactions among the variables and can be used for optimization of the operating parameters in multivariable systems (GÖNEN and AKSU, 2009). From the literature it was found that RSM has been widely used for optimization of biosorption processes mainly in single systems. Only a few studies utilized RSM methodology for statistical analysis of individual and interaction effects of parameters in binary and ternary sorption systems (FEREIDOUNI et al., 2009; PAKSHIRAJAN and SWAMINATHAN, 2009).

Within this context the objective of present study was firstly to quantify the ability of the biosorbent prepared from dried activated sludge to sorb $\mathrm{Cd}^{2+}$ and $\mathrm{Zn}^{2+}$ ions. Equilibrium isotherm models according to Langmuir and Freundlich were used for mathematical description of sorption equilibria in single systems. The second objective was to study the competitive and interaction effects of above mentioned ions in binary $\mathrm{Cd}^{2+}-\mathrm{Zn}^{2+}$ system at various solution $\mathrm{pH}$ values using Response surface methodology (RSM).

\section{Material and methods}

\subsection{Biosorbent preparation}

Activated sludge was obtained from waste water treatment plant in Enviral a.s. (Leopoldov, Slovak Republic) producing fuel ethanol. The sludge was washed twice in deionised water, oven-dried for $72 \mathrm{~h}$ at $90^{\circ} \mathrm{C}$. After drying activated sludge was ground to various particle sizes, from which particle size $<450 \mu \mathrm{m}$ was used in biosorption experiments.

\subsection{Batch sorption experiments in single systems}

The biosorption kinetics was determined by suspending of activated sludge $(2.5$ $\mathrm{g} / \mathrm{L}$, d.w.) in metal solutions ( $\mathrm{pH}$ 6.0) containing $1000 \mu \mathrm{mol} / \mathrm{L} \mathrm{CdCl}_{2}$ or $\mathrm{ZnCl}_{2}$ spiked with ${ }^{109} \mathrm{CdCl}_{2}$ or ${ }^{65} \mathrm{ZnCl}_{2}$. The content was agitated on a reciprocal shaker $(120 \mathrm{rpm})$ at $20^{\circ} \mathrm{C}$ and in time intervals liquid samples were taken and the radioactivity was measured. 
The metal sorption capacity of dried activated sludge was determined by suspending of activated sludge (2.5 g/L, d.w.) in metal solutions ( $\mathrm{pH}$ 6.0) containing $\mathrm{CdCl}_{2}$ or $\mathrm{ZnCl}_{2}$ in concentration range $100-4000 \mu \mathrm{mol} / \mathrm{L}$ spiked with ${ }^{109} \mathrm{CdCl}_{2}$ or ${ }^{65} \mathrm{ZnCl}_{2}$ and exposing for $4 \mathrm{~h}$ at $20^{\circ} \mathrm{C}$ on a reciprocal shaker $(120 \mathrm{rpm})$. To analyze the influence of $\mathrm{pH}$, activated sludge was shaken in metal solutions containing 1000 $\mu \mathrm{mol} / \mathrm{L} \mathrm{CdCl}$ or $\mathrm{ZnCl}_{2}$ spiked with ${ }^{109} \mathrm{CdCl}_{2}$ or ${ }^{65} \mathrm{ZnCl}_{2}$ for $4 \mathrm{~h}$ on a reciprocal shaker at $120 \mathrm{rpm}$ and $20^{\circ} \mathrm{C}$ adjusted to different $\mathrm{pH}$ values $(2.0-9.0)$ by adding $0.5 \mathrm{M} \mathrm{HCl}$ or $0.1 \mathrm{M} \mathrm{NaOH}$. At the end biomass was filtered out, washed twice in deionised water and radioactivity of both activated sludge and liquid phase was measured. The metal uptake was calculated as

$$
Q=V\left(C_{0}-C_{e q}\right) / m
$$

where $Q$ is the uptake ( $\mu \mathrm{mol} / \mathrm{g}, \mathrm{d} . \mathrm{w}.), C_{0}$ and $C_{e q}$ is the initial and the final metal concentrations in solution $(\mu \mathrm{mol} / \mathrm{L})$ and $m$ is the amount of dried biosorbent (given in grams). All experiments were performed in duplicate.

\subsection{Experimental design of binary $C d-Z n$ system}

The Box-Behnken design under Response surface methodology (RSM) was used to investigate interaction and competitive effects in binary metal system $\mathrm{Cd}^{2+}-\mathrm{Zn}^{2+}$. Levels of factors (initial concentrations $\mathrm{C}_{0}$ of $\mathrm{Cd}^{2+}$ and $\mathrm{Zn}^{2+}$ ions and initial $\mathrm{pH}$ of solution) considered for sorption in binary system are shown in Table 1 . The design matrix of 16 experiments is given in Table 3 . Based on the matrix, experiments were performed in Erlenmeyer flasks, activated sludge $(2.5 \mathrm{~g} / \mathrm{L}, \mathrm{d} . \mathrm{w}$.) was added and the content was agitated on a reciprocal shaker $(120 \mathrm{rpm})$ for $4 \mathrm{~h}$ at $20^{\circ} \mathrm{C}$.

Table 1. Levels of factors considered for sorption of $\mathrm{Cd}^{2+}$ and $\mathrm{Zn}^{2+}$ ions from binary system using BoxBehnken design.

\begin{tabular}{cccccc}
\hline \multirow{2}{*}{ Factor } & \multirow{2}{*}{ Unit } & \multicolumn{5}{c}{ Coded levels } \\
\cline { 3 - 6 } & & Factor code & $\mathbf{- 1}$ & $\mathbf{0}$ & $\mathbf{1}$ \\
\hline $\mathrm{C}_{0} \mathrm{Cd}^{2+}$ & $\mu \mathrm{mol} / \mathrm{L}$ & $\mathrm{A}$ & 1000 & 2000 & 3000 \\
$\mathrm{C}_{0} \mathrm{Zn}^{2+}$ & $\mu \mathrm{mol} / \mathrm{L}$ & $\mathrm{B}$ & 1000 & 2000 & 3000 \\
$\mathrm{pH}$ & & $\mathrm{C}$ & 3.0 & 4.5 & 6.0 \\
\hline
\end{tabular}

The behavior of the binary sorption system is explained by the following empirical second-order polynomial model

$$
Q=\beta_{0}+\sum_{i=1}^{k} \beta_{i} x_{i}+\sum_{i=1}^{k} \beta_{i i} x_{i}^{2}+\sum_{1 \leq i \leq j}^{k} \beta_{i j} x_{i} x_{j}
$$

where $Q$ is the predicted response (specific sorption $Q_{e q}$ of both $\mathrm{Cd}$ and $\mathrm{Zn}$ ), $x_{i}, x_{j}$, ..... $x_{k}$ are the input variables $\left(\mathrm{C}_{0} \mathrm{Cd}^{2+}, \mathrm{C}_{0} \mathrm{Zn}^{2+}\right.$ and solution $\left.\mathrm{pH}\right)$ which affect the response $Q, \beta_{0}$ is the intercept term, $\beta_{i}$ is the linear effect, $\beta_{i i}$ is the quadratic effect and $\beta_{i j}$ is the interaction effect (FEREIDOUNI et al., 2009). 


\subsection{Radiometric analysis}

The gamma spectrometric assembly using the well type scintillation detector 54BP54/2-X, NaI(Tl) (Scionix, the Netherlands) and the data processing software Scintivision 32 (ORTEC, USA) were used for ${ }^{109} \mathrm{Cd}$ and ${ }^{65} \mathrm{Zn}$ determination in activated sludge and supernatant fluids at the energy of $\gamma$-photons: ${ }^{109} \mathrm{Cd}-88.04 \mathrm{keV}$ and ${ }^{65} \mathrm{Zn}-1115.52 \mathrm{keV}$. Standardized ${ }^{109} \mathrm{CdCl}_{2}$ solution $(3.937 \mathrm{MBq} / \mathrm{ml} ; 50 \mathrm{mg}$ $\mathrm{CdCl}_{2} / \mathrm{L}$ in $\left.3 \mathrm{~g} / \mathrm{L} \mathrm{HCl}\right)$ and ${ }^{65} \mathrm{ZnCl}_{2}$ solution $(0.8767 \mathrm{MBq} / \mathrm{ml} ; 50 \mathrm{mg} \mathrm{ZnCl} / 2$ in $3 \mathrm{~g} / \mathrm{L}$ $\mathrm{HCl})$ were obtained from the Czech Institute of Metrology, Prague (Czech Republic).

\subsection{Speciation modeling}

Prediction of the speciation of $\mathrm{Cd}$ and $\mathrm{Zn}$ in the aqueous systems as a function of total salt concentration and solution $\mathrm{pH}$ was performed using the Visual MINTEQ (version 2.52) program. Visual MINTEQ 2.52 is a chemical equilibrium computer program that has an extensive thermodynamic database for the calculation of metal speciation, solubility and equilibria (GUSTAFSON, 2004).

\subsection{Data analysis}

To calculate the $Q_{\max }$ values and the corresponding parameters of adsorption isotherms non-linear regression analysis was performed by ORIGIN 7.0 Professional (OriginLab Corporation, Northampton, USA) and GraphPad Prism 5.0 (GraphPad Software, USA). Response surface graphs and regression analysis of the obtained data were performed by Statgraphics Centurion XV (StatPoint Inc., USA) and the Design Expert 7.0 (Stat-Ease, Inc., USA).

\section{Results and discussion}

\section{1 $\mathrm{Cd}^{2+}$ and $\mathrm{Zn}^{2+}$ uptake by activated sludge}

In order to determine the minimum necessary time to reach the sorption equilibrium, the time-course studies on the biosorption of cadmium and zinc ions from single metal systems by biosorbent prepared from dried activated sludge were performed. Fig. 1 shows that biosorption of $\mathrm{Cd}^{2+}$ and $\mathrm{Zn}^{2+}$ ions is a rapid process where equilibrium is reached within several tens minutes. At initial phase driving force is higher and binding sites on activated sludge with higher affinity are occupied. After that time concentration of $\mathrm{Cd}^{2+}$ and $\mathrm{Zn}^{2+}$ ions in solution decreases and the residual binding sites with lower affinity toward metal ions are occupied slowly. The final equilibrium was reached within 4 hours. Such two-phase sorption has been also reported by YANG et al. (2010) in the case of Zn sorption by activated sludge. They found that zinc adsorption capacity increased obviously during the first $60 \mathrm{~min}$ and the final equilibrium was reached within $180 \mathrm{~min}$. 
From Fig. 2 it can be seen that maximum biosorption of both $\mathrm{Cd}^{2+}$ and $\mathrm{Zn}^{2+}$ occurred at $\mathrm{pH}$ 6.0. This curve is characteristic also for $\mathrm{Cd}$ and $\mathrm{Zn}$ biosorption by the moss Rhytidiadelphus squarrosus (PIPÍŠKA et al., 2010) and biosorption of other metal ions on activated sludge, algae and other biosorbents (WANG et al., 2010; LIU et al., 2009; GUNDOGDU et al., 2009). Observed slightly lower biosorption at pH 4.0 and negligible at $\mathrm{pH} 2.0$ is closely related to protonation of binding sites, resulting in competition between $\mathrm{H}^{+}$and $\mathrm{Cd}^{2+}$ or $\mathrm{Zn}^{2+}$ ions for occupancy of the active sites. In the case of $\mathrm{Zn}^{2+}$ at $\mathrm{pH} 8.0$ sharp decrease of biosorption was observed.

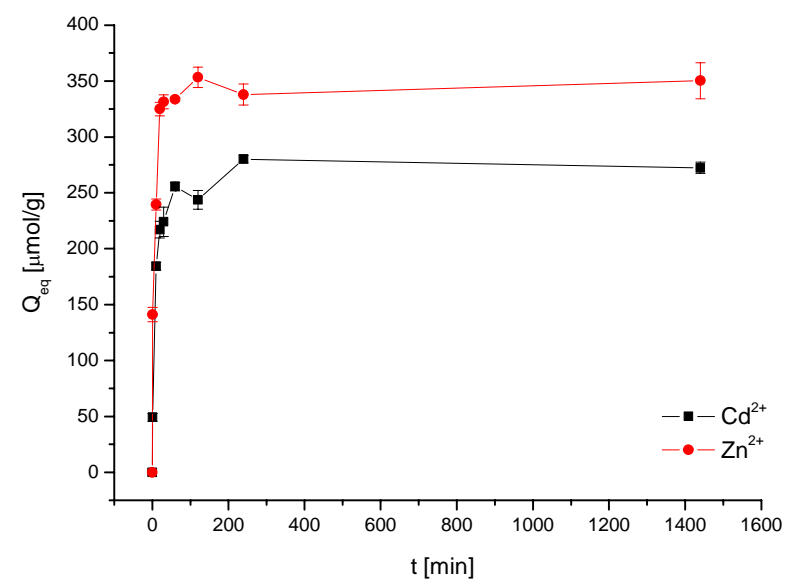

Fig. 1. Effect of contact time on $\mathrm{Cd}^{2+}\left(\mathrm{C}_{0}=1000 \mu \mathrm{mol} / \mathrm{L}, 100 \mathrm{kBq}{ }^{109} \mathrm{CdCl}_{2}\right)$ and $\mathrm{Zn}^{2+}\left(\mathrm{C}_{0}=1000 \mu \mathrm{mol} / \mathrm{L}\right.$, $\left.65 \mathrm{kBq}{ }^{65} \mathrm{ZnCl}_{2}\right)$ ions biosorption by dried activated sludge $\left(2.5 \mathrm{~g} / \mathrm{L}\right.$ d.w.) at $20^{\circ} \mathrm{C}$ and $\mathrm{pH} 6.0$.

It must be pointed out, that the $\mathrm{pH}$ influenced also the level of ionization and speciation of metals in aqueous solution. As can be calculated by Visual MINTEQ speciation program (data not shown) at $\mathrm{pH} 8.0$ besides the divalent cation $\mathrm{Zn}^{2+}$, zinc occurs in solution also in insoluble forms such as $[\mathrm{Zn}(\mathrm{OH})]^{+}$. Therefore the decrease of $\mathrm{Zn}^{2+}$ sorption at higher $\mathrm{pH}$ values $(>\mathrm{pH} 8.0)$ can be caused also by precipitation. According to calculations insoluble cadmium species occurred at $\mathrm{pH}>9.0$. It is reasonable to suppose that the dependence of metal uptake on $\mathrm{pH}$ is related to both the surface functional groups on the biosorbent and the metal speciation in solution.

During sorption experiments pH was not regulated. From Fig. 2 it is evident that the equilibrium $\mathrm{pH}$ increased after biosorption experiments what indicates that functional groups on the surface accumulate besides $\mathrm{Cd}^{2+}$ and $\mathrm{Zn}^{2+}$ ions simultaneously $\mathrm{H}^{+}$ions. Similar behaviour observed also CHEN et al. (2002) in $\mathrm{Cu}$ sorption by activated sludge.

Several mechanisms of heavy metals uptake by activated sludge have been proposed (WANG et al., 2010; LAURENT et al., 2010). Short-term cation uptake is generally regarded as an abiotic process governed by: surface complexation of cations with exposed functional groups (carboxyl-, sulfhydryl-, amine- etc.) on the biosorbent; ion exchange; coordination and chelation of metals; adsorption or by precipitation of solid phases on the cell walls. 

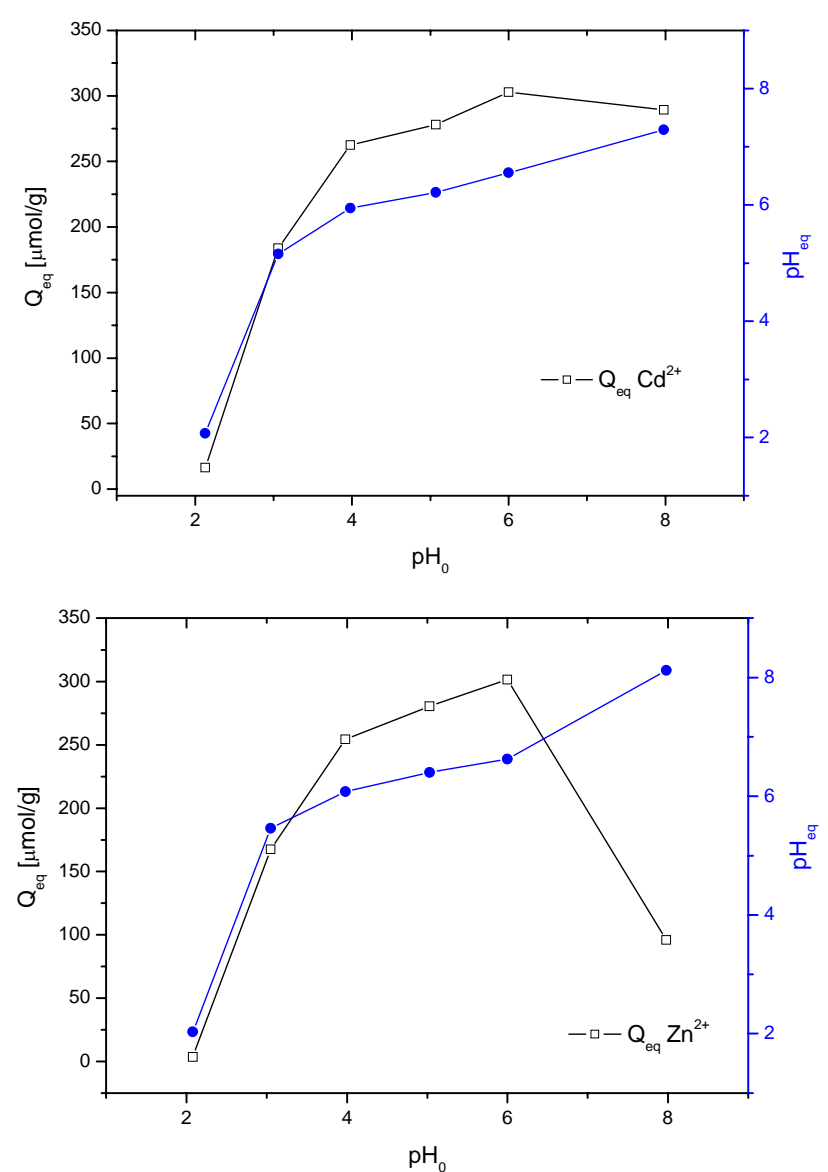

Fig. 2. Effect of initial $\mathrm{pH}$ on $\mathrm{Cd}^{2+}$ and $\mathrm{Zn}^{2+}$ ions $\left(\mathrm{c}_{0}=1000 \mu \mathrm{mol} / \mathrm{L}\right)$ sorption by dried activated sludge $(2.5$ $\mathrm{g} / \mathrm{L}$, d.w.) at $20^{\circ} \mathrm{C}$; (-O-) represents shifts in $\mathrm{pH}$ after biosorption.

\subsection{Sorption equilibrium in single systems}

Two well known adsorption isotherm models - Langmuir (Eq. 3) and Freundlich (Eq. 4) were applied for the analysis of the experimental data in single sorption systems.

$$
\begin{gathered}
Q_{e q}=\frac{b Q_{\max } C_{e q}}{1+b C_{e q}} \\
Q_{e q}=K C_{e q}^{(1 / n)}
\end{gathered}
$$

Parameters of these models provide an insight into the sorption process, reflect the nature of the sorbent, surface properties as well as the degree of the affinity of the 
sorbents and can be used to compare biosorption performance (VOLESKY, 2003). The Langmuir and Freundlich isotherms were fitted to the equilibrium data for $\mathrm{Cd}^{2+}$ and $\mathrm{Zn}^{2+}$ sorption on dried activated sludge. Isotherm curves and parameters of the models determined from the experimental data using non-linear regression analysis are reported in Fig. 3, 4 and Table 2.

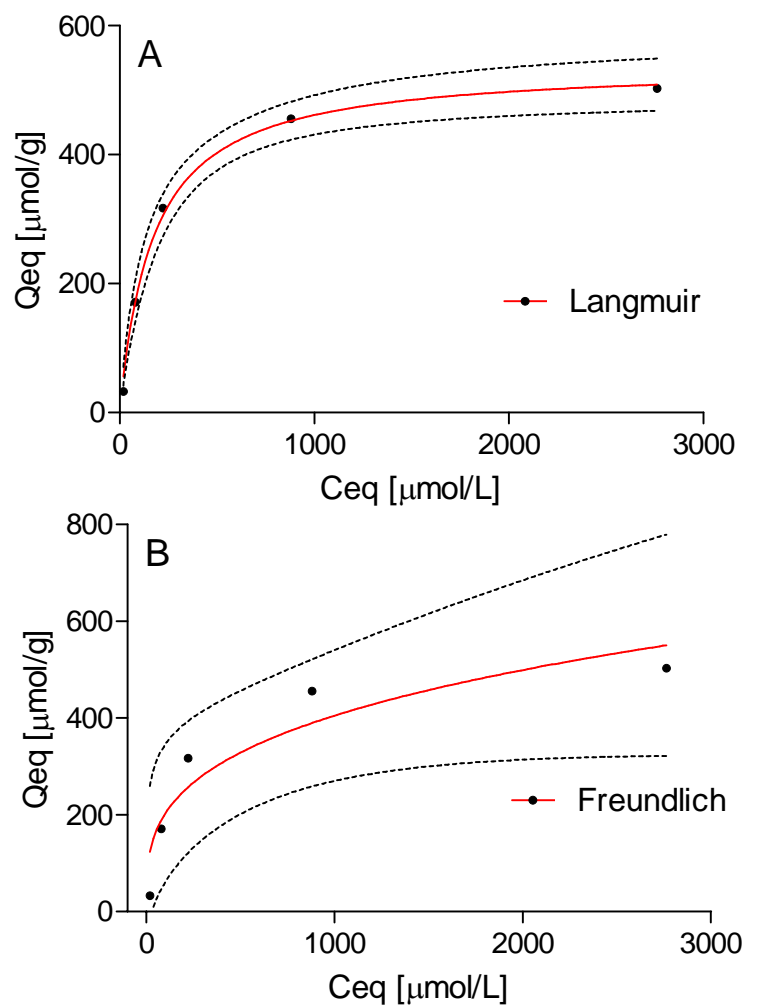

Fig. 3. Isotherms for the sorption of $\mathrm{Zn}^{2+}$ ions by dried activated sludge at $20^{\circ} \mathrm{C}$ and $\mathrm{pH} 6.0$ according to Langmuir (A) and Freundlich (B). Data points represent experimental results, curves represent the calculated values from isotherm models, dotted lines represent the $95 \%$ confidence interval.

The Langmuir isotherm fits the data of both $\mathrm{Cd}^{2+}$ and $\mathrm{Zn}^{2+}$ ions sorption by dried activated sludge better than the Freundlich isotherm, as is demonstrated by higher values of coefficient of determination $\left(R^{2}\right)$, the more homogeneous standard deviation of each observed parameter and by the lower the sum of squares $(R S S)$ values obtained as well as standard deviation of the residuals $\left(S_{y, x}\right)$ (Table 2). Also HAMMAINI et al. (2007) found that the sorption of $\mathrm{Cd}^{2+}$ and $\mathrm{Zn}^{2+}$ ions by activated sludge was well described using the Langmuir isotherm.

The maximum sorption capacity $Q_{\max }$ obtained from Langmuir isotherm for $\mathrm{Cd}^{2+}$ was $510 \pm 17 \mu \mathrm{mol} / \mathrm{g}$ at $\mathrm{pH}$ 6.0. Slightly higher value of $Q_{\max }$ was observed in the case of $\mathrm{Zn}^{2+}$ sorption, $540 \pm 16 \mu \mathrm{mol} / \mathrm{g}$ at $\mathrm{pH}$ 6.0. The affinity constant $b$ of the isotherms corresponds to the initial gradient, which indicates the biosorbent affinity at low 

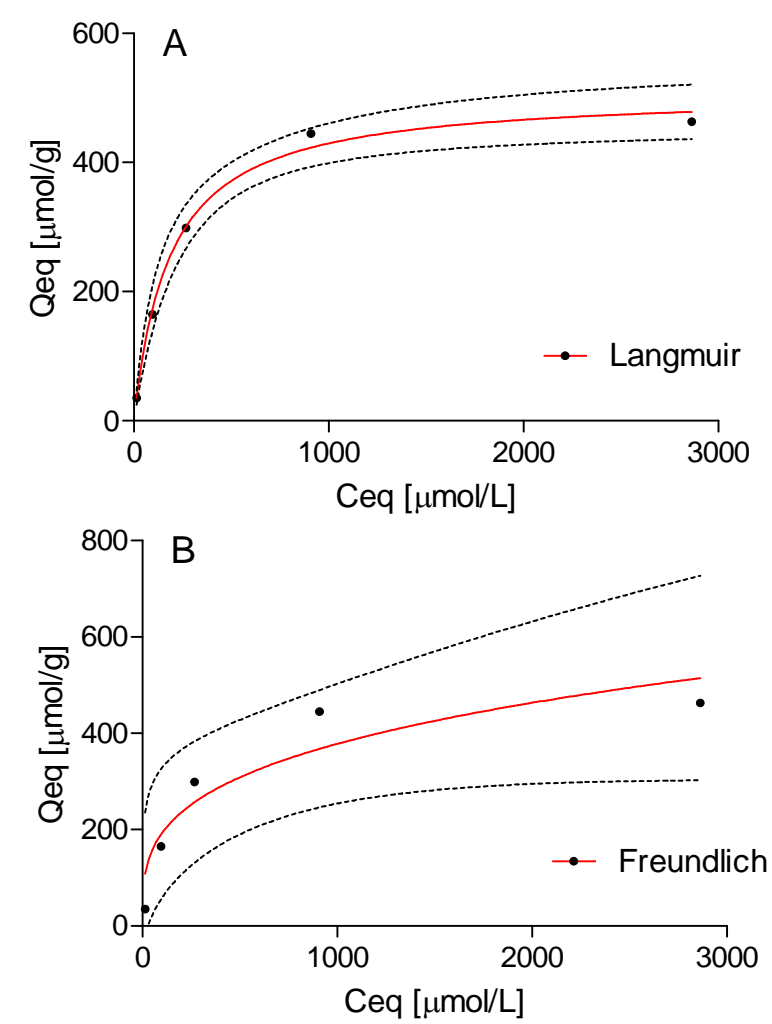

Fig. 4. Isotherms for the sorption of $\mathrm{Cd}^{2+}$ ions by dried activated sludge at $20^{\circ} \mathrm{C}$ and $\mathrm{pH} 6.0$ according to Langmuir (A) and Freundlich (B). Data points represent experimental results, curves represent the calculated values from isotherm models, dotted lines represent the $95 \%$ confidence interval.

Table 2. Langmuir and Freundlich parameters for the sorption of $\mathrm{Cd}^{2+}$ and $\mathrm{Zn}^{2+}$ ions by dried activated sludge obtained by non-linear regression analysis.

\begin{tabular}{|c|c|c|c|c|c|c|c|c|}
\hline Model & $\begin{array}{c}\text { Metal } \\
\text { ion }\end{array}$ & $\begin{array}{c}\boldsymbol{Q}_{\max } \\
{[\mu \mathrm{mol} / \mathrm{g}]}\end{array}$ & $\begin{array}{c}\boldsymbol{b} \\
{[\mathrm{L} / \mu \mathrm{mol}]}\end{array}$ & $\begin{array}{c}\boldsymbol{K} \\
{[\mathrm{L} / \mathrm{g}]}\end{array}$ & $1 / n$ & $R^{2}$ & RSS & $S_{y, x}$ \\
\hline \multirow{2}{*}{ 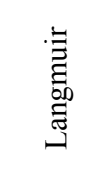 } & $\mathrm{Zn}^{2+}$ & $540 \pm 16$ & $\begin{array}{c}0.006 \pm \\
0.001\end{array}$ & - & - & 0.995 & 723 & 15.5 \\
\hline & $\mathrm{Cd}^{2+}$ & $510 \pm 17$ & $\begin{array}{c}0.005 \pm \\
0.001\end{array}$ & - & - & 0.994 & 769 & 16.0 \\
\hline \multirow{2}{*}{ 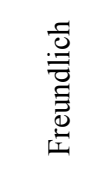 } & $\mathrm{Zn}^{2+}$ & - & - & $\begin{array}{c}50.3 \pm \\
29.4\end{array}$ & $\begin{array}{c}0.30 \pm \\
0.08\end{array}$ & 0.877 & 18817 & 79.2 \\
\hline & $\mathrm{Cd}^{2+}$ & - & - & $\begin{array}{c}49.9 \pm \\
28.9\end{array}$ & $\begin{array}{c}0.29 \pm \\
0.08\end{array}$ & 0.878 & 16347 & 73.8 \\
\hline
\end{tabular}

concentrations of metal ions. A greater initial gradient corresponds to a higher affinity constant (SHENG et al., 2007). From Fig. 3 and 4 it is evident that the cadmium and 
zinc isotherms have similar behavior at lower equilibrium concentrations. In the case of $b$, cadmium recorded $0.005 \pm 0.001 \mathrm{~L} / \mu \mathrm{mol}$ compared to $0.006 \pm 0.001 \mathrm{~L} / \mu \mathrm{mol}$ for zinc indicating slightly higher affinity of activated sludge for zinc ions. It should be realized that despite the fact that Langmuir isotherm offers no insights into the mechanism of biosorption (LIU and LIU, 2008) it remains a convenient tool for comparing equilibrium data on a quantitative basis (determination of maximum sorption capacity $Q_{\max }$ and affinity parameters $b$ ) and providing information on biosorption potential.

\subsection{Experimental design of binary $C d-Z n$ system}

Box-Behnken design under the Response surface methodology (RSM) was used for investigation of interaction and competitive effects between variables in binary system Cd-Zn. According to preliminary experiments and our previous studies (PIPÍŠKA et al., 2010; PIPÍŠKA et al., 2008) the sorption capacity of biosorbent in multi-component systems mainly depends on the initial concentration of primary ion and co-ions in sorption system and on the solution $\mathrm{pH}$. Therefore, initial concentration of $\mathrm{Cd}$ and $\mathrm{Zn}$ and solution $\mathrm{pH}$ were used as process variables in experimental design (Table 3 ) and two responses $-Q_{e q}(\mathrm{Cd})$ and $Q_{e q}(\mathrm{Zn})$ were studied simultaneously.

Table 3. Box-Behnken experimental design matrix and experimental and predicted values of sorption capacity $\left(Q_{e q}\right)$ of $\mathrm{Cd}^{2+}$ and $\mathrm{Zn}^{2+}$ ions by dried activated sludge from binary system $\mathrm{Cd}-\mathrm{Zn}$. $\mathrm{A}-\mathrm{C}_{0} \mathrm{Cd}$ $(\mu \mathrm{mol} / \mathrm{L}), \mathrm{B}-\mathrm{C}_{0} \mathrm{Zn}(\mu \mathrm{mol} / \mathrm{L}), \mathrm{C}-\mathrm{pH}$.

\begin{tabular}{|c|c|c|c|c|c|c|c|}
\hline \multirow[b]{2}{*}{$\begin{array}{l}\text { Run } \\
\text { order }\end{array}$} & \multicolumn{3}{|c|}{ Factor } & \multicolumn{2}{|c|}{$Q_{e q} \mathrm{Cd}$} & \multicolumn{2}{|c|}{$Q_{e q} \mathrm{Zn}$} \\
\hline & A & B & $\mathrm{C}$ & $\begin{array}{c}Q_{e q} \\
\text { (experimental) } \\
(\mu \mathrm{mol} / \mathrm{g})\end{array}$ & $\begin{array}{c}Q_{e q} \\
\text { (predicted) } \\
(\mu \mathrm{mol} / \mathrm{g})\end{array}$ & $\begin{array}{c}Q_{e q} \\
\text { (experimental) } \\
(\mu \mathrm{mol} / \mathrm{g})\end{array}$ & $\begin{array}{c}Q_{e q} \\
\text { (predicted) } \\
(\mu \mathrm{mol} / \mathrm{g})\end{array}$ \\
\hline 1 & 1000 & 1000 & 4.5 & 205.8 & 206.5 & 178.0 & 179.2 \\
\hline 2 & 3000 & 1000 & 4.5 & 321.0 & 321.7 & 113.2 & 122.8 \\
\hline 3 & 1000 & 3000 & 4.5 & 130.7 & 130.0 & 312.0 & 302.4 \\
\hline 4 & 3000 & 3000 & 4.5 & 261.4 & 260.7 & 226.2 & 226.9 \\
\hline 5 & 1000 & 2000 & 3 & 93.77 & 90.64 & 138.1 & 145.5 \\
\hline 6 & 3000 & 2000 & 3 & 211.2 & 208.0 & 118.3 & 115.3 \\
\hline 7 & 1000 & 2000 & 6 & 170.8 & 173.9 & 284.9 & 287.8 \\
\hline 8 & 3000 & 2000 & 6 & 299.3 & 302.4 & 193.3 & 185.9 \\
\hline 9 & 2000 & 1000 & 3 & 180.9 & 183.4 & 75.86 & 69.18 \\
\hline 10 & 2000 & 3000 & 3 & 132.7 & 136.5 & 154.0 & 156.1 \\
\hline 11 & 2000 & 1000 & 6 & 297.8 & 294.0 & 151.1 & 148.9 \\
\hline 12 & 2000 & 3000 & 6 & 206.0 & 203.5 & 282.6 & 289.3 \\
\hline 13 & 2000 & 2000 & 4.5 & 242.5 & 245.0 & 213.3 & 214.6 \\
\hline 14 & 2000 & 2000 & 4.5 & 242.5 & 245.0 & 213.3 & 214.6 \\
\hline 15 & 2000 & 2000 & 4.5 & 254.5 & 245.0 & 227.8 & 214.6 \\
\hline 16 & 2000 & 2000 & 4.5 & 241.1 & 245.0 & 198.4 & 214.6 \\
\hline
\end{tabular}


The behavior of the binary sorption system $\mathrm{Cd}-\mathrm{Zn}$ is explained by the following quadratic models determined by multiple regression analysis:

$$
\begin{aligned}
& Q_{e q}(C d)=-382+0.097 \times c 0 C d-2.1 \cdot 10^{-5} \times c 0 Z n+194 \times p H-1.3 \cdot 10^{-5} \times c 0^{2} C d-2.3 \cdot 10^{-6} \times \\
& c 0^{2} \mathrm{Zn}-17.03 \times p H^{2}+3.9 \cdot 10^{-6} \times c 0 C d \times c 0 Z n+0.0019 \times c 0 \times p H-0.007 \times c 0 Z n \times p H \\
& Q_{e q}(Z n)=-394+0.008 \times c 0 C d+0.075 \times c 0 Z n+187 \times p H+5.5 \cdot 10^{-6} \times c 0^{2} C d-1.2 \cdot 10^{-5} \times c 0^{2} Z n \\
& -16.2 \times p H^{2}-4.8 \cdot 10^{-6} \times c 0 C d \times c 0 Z n-0.012 \times c 0 \times p H+0.009 \times c 0 Z n \times p H
\end{aligned}
$$

The adequacy of the models was further justified through ANOVA (data not shown). The model $F$-values of 246 (for $\mathrm{Cd}^{2+}$ sorption) and 58.3 (for $\mathrm{Zn}^{2+}$ sorption) and values of $P<0.0001$ indicate that both models are significant. Good agreement between experimental and predicted values of sorption capacity $Q_{e q}$ (Table 3 ) confirmed high values of coefficient of determination $\left(R^{2}\right), 0.997$ (for $\left.\mathrm{Cd}^{2+}\right)$ and $0.987\left(\right.$ for $\left.\mathrm{Zn}^{2+}\right)$. Equations 5 and 6 represent the quantitative effect of the variables (initial concentration of $\mathrm{Cd}$ and $\mathrm{Zn}$, solution $\mathrm{pH})$ and their interactive effects on the $Q_{e q}(\mathrm{Cd})$ and $Q_{e q}(\mathrm{Zn})$ in binary system $\mathrm{Cd}-\mathrm{Zn}$. A positive sign in the equation implies a synergistic effect of the variables, while a negative sign indicates an antagonistic effect.

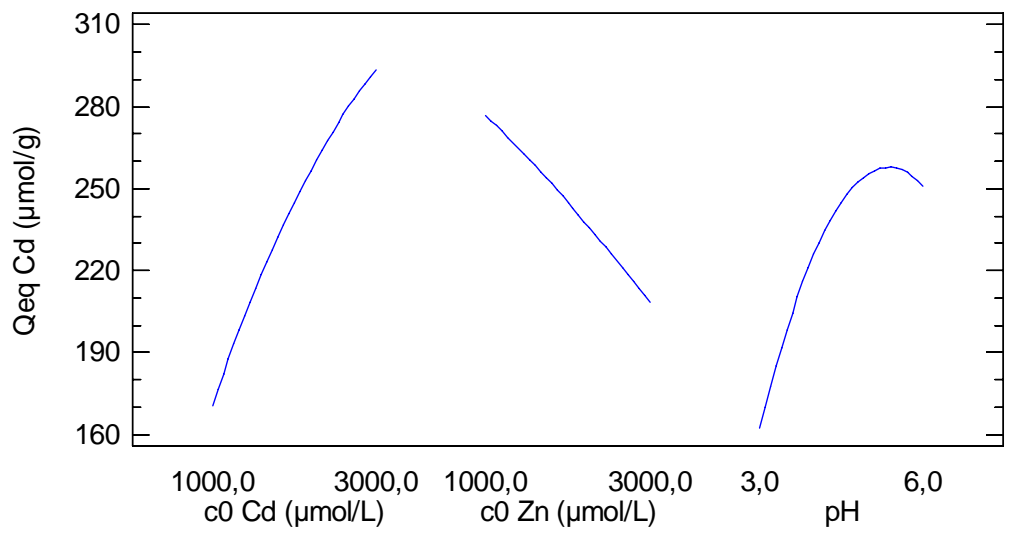

Fig. 5. Main effects plot for $\mathrm{Cd}^{2+}$ biosorption by dried activated sludge from binary system $\mathrm{Cd}-\mathrm{Zn}$.

Fig. 7A, B, C illustrate the three-dimensional response surface plots of the quadratic model (Eq. 5) for $\mathrm{Cd}^{2+}$ sorption from binary system $\mathrm{Cd}-\mathrm{Zn}$. The combined effect of initial $\mathrm{Cd}^{2+}$ concentration and $\mathrm{pH}$ on $\mathrm{Cd}^{2+}$ sorption by dried activated sludge at various concentrations of zinc as co-ion is shown. It is evident that $\mathrm{Cd}^{2+}$ uptake increased with increasing of initial solution $\mathrm{pH}$ as well as with initial $\mathrm{Cd}^{2+}$ concentration. On the contrary, increasing $\mathrm{Zn}^{2+}$ concentration from 1000 to 3000 $\mu \mathrm{mol} / \mathrm{L}$ diminished $\mathrm{Cd}^{2+}$ sorption as a result of competition between metal ions (Fig. 5). Increase in solution $\mathrm{pH}$ and initial $\mathrm{Zn}^{2+}$ sorption caused increase in $\mathrm{Zn}^{2+}$ sorption as can be seen from main effects plot (Fig. 6). Similarly, increase in $\mathrm{Cd}^{2+}$ concentration decreased $\mathrm{Zn}^{2+}$ sorption from binary system $\mathrm{Cd}-\mathrm{Zn}$. 


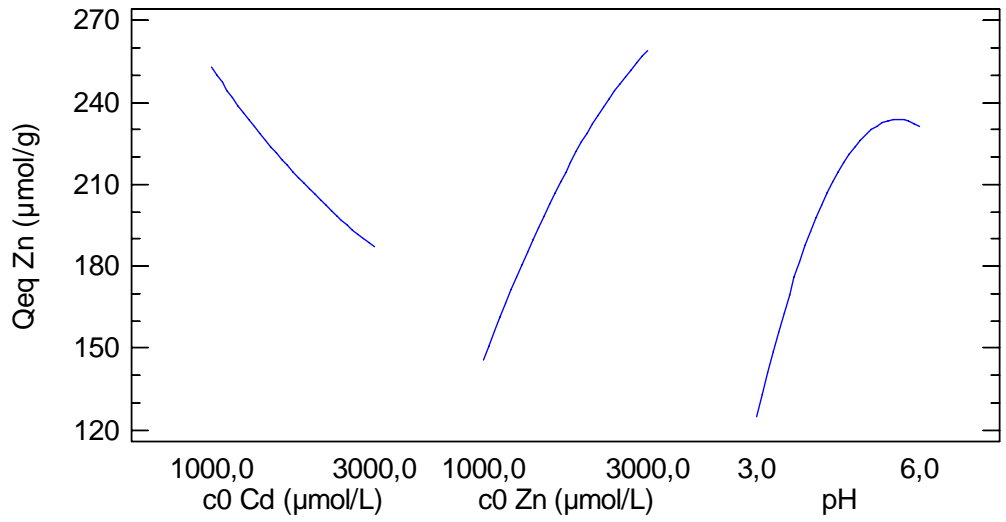

Fig. 6. Main effects plot for $\mathrm{Zn}^{2+}$ biosorption by dried activated sludge from binary system $\mathrm{Cd}-\mathrm{Zn}$.
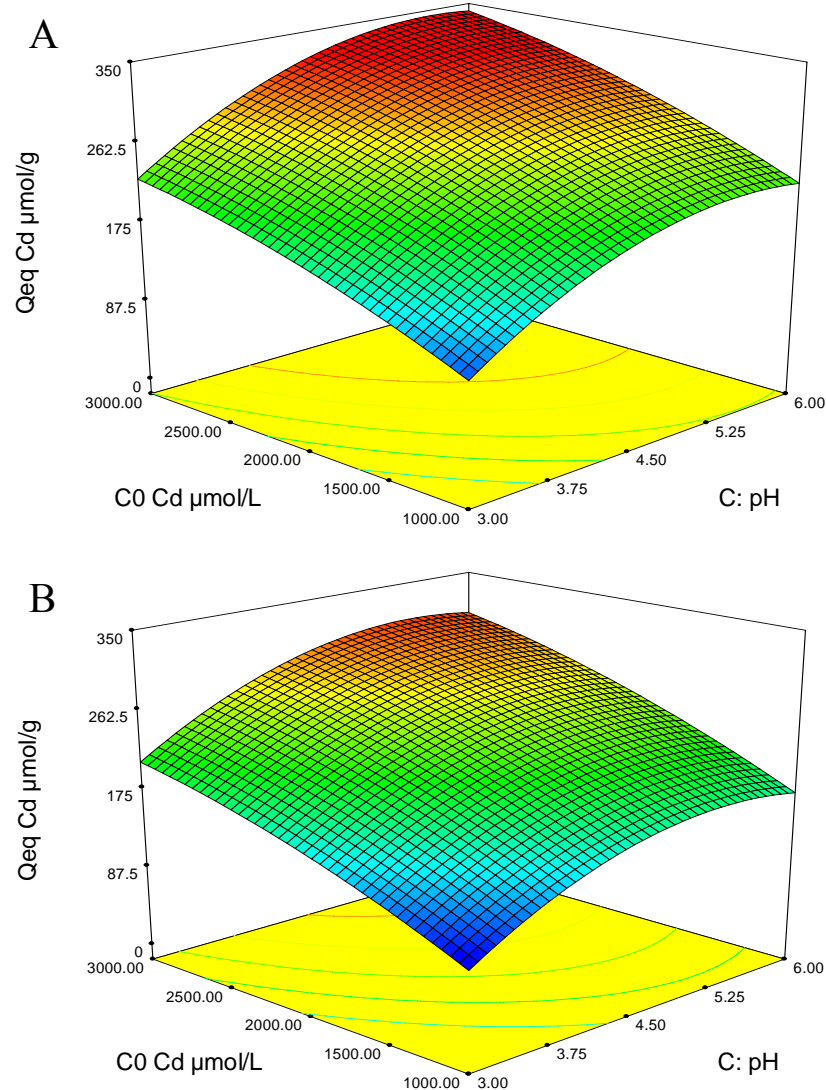


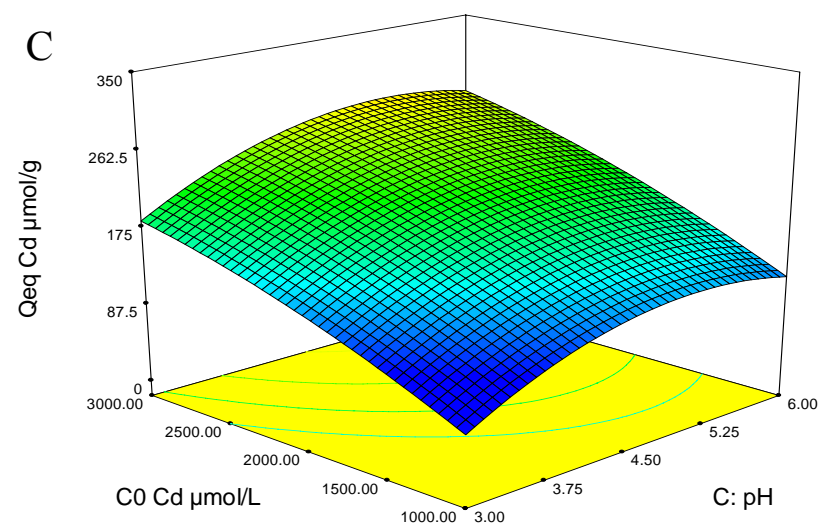

Fig. 7. Response surface plots showing the effect of $\mathrm{pH}$ and initial $\mathrm{Cd}^{2+}$ concentration on $\mathrm{Cd}^{2+}$ biosorption by dried activated sludge ( $2.5 \mathrm{~g} / \mathrm{L}$ d.w.) at $20^{\circ} \mathrm{C}$ and different concentrations of $\mathrm{Zn}^{2+}$ as competing ion (A) 1000 $\mu \mathrm{mol} / \mathrm{L}$, (B) $2000 \mu \mathrm{mol} / \mathrm{L},(C) 3000 \mu \mathrm{mol} / \mathrm{L}$.

Maximum sorption capacities of the activated sludge were $321 \mu \mathrm{mol} \mathrm{Cd}{ }^{2+} / \mathrm{g}$ and $312 \mu \mathrm{mol} \mathrm{Zn^{2+ }} / \mathrm{g}$. It was found that dried activated sludge in binary system Cd-Zn has higher affinity for $\mathrm{Cd}^{2+}$ ions when $\mathrm{Cd}^{2+}$ and $\mathrm{Zn}^{2+}$ are present in equimolar ratio $1: 1$ (Table 3) comparing with higher affinity to $\mathrm{Zn}^{2+}$ in single systems. This is consistent with the hypothesis that variance in affinity in multi-component systems could be attributed to different ionic characteristics of metal ions (PAKSHIRAJAN and SWAMINATHAN, 2009).

\section{Conclusions}

Biosorption of $\mathrm{Cd}^{2+}$ and $\mathrm{Zn}^{2+}$ from aqueous solution by dried activated sludge is a rapid and $\mathrm{pH}$ dependent process. Maximum uptake of metals was found to occur at $\mathrm{pH}$ 6. The experimental equilibrium data of the single-component systems for $\mathrm{Cd}^{2+}$ and $\mathrm{Zn}^{2+}$ ions have been well described by the Langmuir isotherm and the maximum sorption capacity $Q_{\max }$ were $540 \pm 16 \mu \mathrm{mol} / \mathrm{g}$ for $\mathrm{Zn}^{2+}$ and $510 \pm 17 \mu \mathrm{mol} / \mathrm{g}$ for $\mathrm{Cd}^{2+}$ ions. The use of RSM revealed the existence of interaction and competitive effects between variables in binary system $\mathrm{Cd}-\mathrm{Zn} . \mathrm{Cd}^{2+}$ uptake increased with increasing of initial solution $\mathrm{pH}$ as well as with initial $\mathrm{Cd}^{2+}$ concentration. On the contrary, increasing $\mathrm{Zn}^{2+}$ concentration from 1000 to $3000 \mu \mathrm{mol} / \mathrm{L}$ diminished $\mathrm{Cd}^{2+}$ sorption as a result of competition between metal ions. Activated sludge in binary system $\mathrm{Cd}-\mathrm{Zn}$ has higher affinity for $\mathrm{Cd}^{2+}$ comparing with $\mathrm{Zn}^{2+}$ ions when $\mathrm{Cd}^{2+}$ and $\mathrm{Zn}^{2+}$ are present in equimolar ratio 1:1. RSM appears to be a useful tool for obtaining interaction and competitive effects in binary systems since it requires less reagents and experimentation time.

\section{References}

CHEN, J.P., LIE, D., WANG, L., WU, S., ZHANG, B.: Dried waste activated sludge as biosorbents for metal removal: adsorptive characterization and prevention of organic leaching. J. Chem. Technol. Biotechnol., 77, 2002, 657-662. 
FEREIDOUNI, M., DANESHI, A., YOUNESI, H.: Biosorption equilibria of binary Cd(II) and Ni (II) systems onto Saccharomyces cerevisiae and Ralstonia eutropha cells: Application of response surface methodology. J. Hazard. Mater., 168, 2009, 1437-1448.

GHODBANE, I., NOURI, L., HAMDAOUI, O., CHIHA, M.: Kinetic and equilibrium study for the sorption of cadmium (II) ions from aqueous phase by eucalyptus bark. J. Hazard. Mater., 152, 2008, 148-158.

GÖNEN, F., AKSU, Z.: Single and binary dye and heavy metal bioaccumulation properties of Candida tropicalis: Use of response surface methodology (RSM) for the estimation of removal yields. J. Hazard. Mater., 172, 2009, 1512-1519.

GUNDOGDU, A., OZDES, D., DURAN, C., BULUT, V.N., SOYLAK, M., SENTURK, H.B.: Biosorption of $\mathrm{Pb}(\mathrm{II})$ ions from aqueous solution by pine bark (Pinus brutia Ten.). Chem. Eng. J., 153, 2009, 62-69.

GUSTAFSON, J.P.: Visual-MINTEQ, version 2.52. (2004) http://www.lwr.kth.se/ english/OurSoftware/Vminteq.

HAMMAINI, A., GONZÁLEZ, F., BALLESTER, A., BLÁZQUEZ, M.L., MUNOZ, J.A.: Biosorption of heavy metals by activated sludge and their desorption characteristics. J. Environ. Manag., 84, 2007, 419-426.

KANG, S., LEE, J., KIMA, K.: Biosorption of $\mathrm{Cr}(\mathrm{III})$ and $\mathrm{Cr}(\mathrm{VI})$ onto the cell surface of Pseudomonas aeruginosa. Biochem. Eng. J., 36, 2007, 54-58.

LAURENT, J., CASELlAS, M., DAGOT, C.: Heavy metals uptake by sonicated activated sludge: Relation with floc surface properties. J. Hazard. Mater., 162, 2010, 652-660.

LIU, Y., CAO, Q., LUO, F., CHEN, J.: Biosorption of $\mathrm{Cd}^{2+}, \mathrm{Cu}^{2+}, \mathrm{Ni}^{2+}$ and $\mathrm{Zn}^{2+}$ ions from aqueous solutions by pretreated biomass of brown algae. J. Hazard. Mater., $163,2009,931-938$.

LIU, Y., LIU, Y-J.: Biosorption isotherms, kinetics and thermodynamics. Sep. Purif. Technol., 61, 2008, 229-242.

MA, W., TOBIN, J.M.: Development of multimetal binding model and application to binary metal biosorption onto peat biomass. Water Res., 37, 2003, 3967-3977.

MUNE, M.A.M., MINKA, S.R., MBOME, I.L.: Response surface methodology for optimisation of protein concentrate preparation from cowpea (Vigna unguiculata (L.) Walp.). Food Chem., 110, 2008, 735-741.

NAJA, G.M., VOLESKY, B., MURPHY, V.: Biosorption, metals, In: M. FLICKINGER (Ed.), Encyclopedia of Industrial Biotechnology, Bioprocess, bioseparation, and cell technology Wiley Interscience, New York, 2010.

NAYAK, H., LAHIRI, S.: Biosorption of toxic, heavy, no-carrier-added radionuclides by calcium alginate beads. J. Radioanal. Nucl. Chem., 267, 2006, 59-65.

PAKSHIRAJAN, K., SWAMINATHAN, T.: Biosorption of lead, copper, and cadmium by Phanerochaete chrysosporium in ternary metal mixtures: statistical analysis of individual and interaction effects. Appl. Biochem. Biotechnol., 158, 2009, 457-469.

PIPÍŠKA, M., HORNÍK, M., REMENÁROVÁ, L., AUGUSTÍN, J., LESNÝ, J.: Biosorption of cadmium, cobalt and zinc by moss Rhytidiadelphus squarrosus in the single and binary component systems. Acta Chim. Slov., 57, 2010, 163-172. 
PIPÍŠKA, M., HORNÍK, M., VRTOCH, L., AUGUSTÍN, J., LESNÝ, J.: Biosorption of $\mathrm{Zn}$ and Co ions by Evernia prunastri from single and binary metal solutions. Chem. Ecol., 24, 2008, 181-190.

SHENG, P.X., TING, Y.P., CHEN, J.P.: Biosorption of heavy metal ions $(\mathrm{Pb}, \mathrm{Cu}$, and $\mathrm{Cd}$ ) from aqueous solutions by the marine alga Sargassum sp. in single- and multiple-metal systems. Ind. Eng. Chem. Res., 46, 2007, 2438-2444.

VOLESKY, B.: Biosorption process simulation tools. Hydrometallurgy, 71, 2003, 179-190.

WANG, X-H., SONG, R-H., TENG, S-X., GAO, M-M., NI, J-Y., LIU, F-F., WANG, S-G., GAO, B-Y.: Characteristics and mechanisms of $\mathrm{Cu}(\mathrm{II})$ biosorption by disintegrated aerobic granules. J. Hazard. Mater., 179, 2010, 431-437.

YANG, CH., WANG, J., LEI, M., XIE, G., ZENG, G., LUO, S.: Biosorption of zinc (II) from aqueous solution by dried activated sludge. J. Environ. Sci., 22, 2010, $675-680$.

ZOLGHARNEIN, J., ADHAMI, Z., SHAHMORADI, A., MOUSAVI, S.N.: Optimization of removal of methylene blue by Platanus tree leaves using response surface methodology. Anal. Sci., 26, 2010, 111-116. 